DOI: 10.1515/ausfm-2018-0001

\title{
Tableaux Vivants, Early Cinema, and Beauty-as-Attraction
}

\author{
Daniel Wiegand \\ University of Zurich (Switzerland) \\ E-mail: Daniel.wiegand@fiwi.uzh.ch
}

\begin{abstract}
This article offers a case study in intermediality and explores relationships between tableaux vivants performances and early cinema around 1900. It locates processes of intermedial exchange not only at the level of form but also at the level of modes of address and reception. More specifically, the study is concerned with how bourgeois notions of beauty were transferred to the film image and reconciled with the attraction value of cinema. As a discussion of early film theory reveals, the concept of "beauty in film" depended on a taming of filmic motion, something that had already been realized in performance practices of tableaux vivants. In the subsequent analysis of the cultural context of tableaux vivants in European variety theatres, I outline a specific mode of address, which I term "beautyas-attraction:" an overlap of the older aesthetics of the beautiful and the more modern aesthetics of attraction. Through concluding film analysis, I show how tableaux vivants became a model and source of inspiration for early cinema, thus bringing to fruition the two-fold address of beauty-asattraction in a new media context. ${ }^{1}$
\end{abstract}

Keywords: early cinema, intermediality, film theory, art, painting.

"Living photographs are about as far from being things of beauty as anything possibly could be."

Cecil Hepworth (1896, quoted in Bottomore 1996, 137.)

Film pioneer Cecil Hepworth's harsh judgment (quoted in the motto) notwithstanding, many of the earliest films and film programmes strove to attain painterly effects and were advertised as especially artistic and beautiful. Examples include the scenic views of waterfalls and sea waves by the American Mutoscope and Biograph Company (see Musser 2006), the many filmed versions of famous

1 A longer version of this article was published in German in Film Bild Kunst: Visuelle Ästhetik des vorklassischen Stummfilms, ed. Jörg Schweinitz and Daniel Wiegand. Marburg: Schüren, 2016 (Zürcher Filmstudien 34). I would like to thank the series editors for permission to publish a shortened version in English. 
paintings by producers such as Lumière, Pathé, and Gaumont (see Robert 2018), and the screenings by female itinerant exhibitor "Mme Olinka," advertised as "living watercolour photographs of the highest artistic value." These artistic tendencies came to the fore around 1910, when international film companies increasingly catered to highbrow audiences and intellectuals began to write about film as a valid cultural expression. In Germany in particular, writers like Georg Melcher, Hermann Häfker, and Herbert Tannenbaum discussed the art value of film and devised ideas for artistic film programmes, partly modelled on the notion of Richard Wagner's Gesamtkunstwerk. Many of these discussions revolved around ideas of film as "painting in motion" and as an expression of beauty. ${ }^{3}$

Beauty was a key concept of bourgeois culture at the time, especially in the German Bildungsbürgertum. ${ }^{4}$ The ideas associated with it were largely derived from an everyday understanding of classical idealist aesthetics and neo-platonic thought that circulated in popular books and magazines. They implied the equation of Beauty and Art, the association of the Beautiful with the True and the Good (at the time often capitalized in English), and an emphasis on harmony and perfect proportions. These conceptions were often modelled on the classical art of antiquity, including its afterlife in neoclassicism and contemporary art, as taught and practiced at the big art academies. Although these ideas and preferences contradicted more recent trends in philosophical aesthetics and the emerging art movements of modernity, they nevertheless profoundly shaped the cultural life of the bourgeoisie and its interaction with mass culture. Thus, attempts to adapt beauty as a valid category for the new medium of film were inherently contradictory. As previous research has abundantly shown, many early films were indebted to the aesthetics of attraction rather than to the aesthetics of classical art. In many instances, films aimed less at contemplative perception than at the satisfaction of Schaulust, that is, of sensation-seeking visual curiosity (see e.g. Gunning 1986 and 1995; Schwartz 1995). According to Tom Gunning, early cinema's "aesthetic of attraction" was, in fact, almost an "anti-aesthetic" $(1995,123)$ in terms of traditional notions of art reception. ${ }^{5}$

$2 \quad$ Der Artist vol. 668 (1897), n.p.

3 Some of these authors' texts have been translated into English in Kaes/Baer/Cowan 2016. For texts in German see Schweinitz 1992 and Diederichs 2004.

4 While this article discusses international film production, the theoretical discourse examined is largely German. Among other things, the titles of popular middle-class periodicals such as Die Schönheit (Beauty) and Schönheitskult (Cult of Beauty) or events like the 1909 "SchönheitAbende” (Beauty Nights) in Berlin (see Runge 2009, 25-39) point to the significance of the notion of beauty in turn-of-the-century Germany.

$5 \quad$ For an opposing, and equally justified point of view on early cinema see Musser 2006. 
In the present essay, I examine the arguments, aesthetic choices, and reception strategies that were necessary in order to connect the cinematic image to conventionally bourgeois notions of beauty. ${ }^{6}$ As I will show, the idea of the "beautiful film image" in the early $20^{\text {th }}$ century resulted from a complex interplay of theoretical discourses, stylistic practices, and novel audience expectations. Specifically, I argue that the aesthetics of motion in early film images had the capacity to contradict common notions of beauty and was therefore often tamed or domesticated - both in theory and in cinematic practice - in order to pave the way for the "beautiful film image" as a theoretical concept and creative product.

This domestication was not a mere process of suppression. In fact, I argue that a number of films from around 1900 used a specific mode of address, which emphasized what I call "beauty-as-attraction." This was an amalgamation of the aesthetics of the beautiful (associated with traditional art forms such as painting and sculpture) and the aesthetics of attraction (which characterized much of the era's popular visual culture). My claim is that this mode of address had existed before - and continued to exist - in variety theatre, and more specifically in the performance tradition of tableaux vivants, which thus served as a model and source of inspiration for these early films. The present article is thus concerned with issues of intermediality, locating the interaction between classical art forms, early film, and tableaux vivants at the level of specific modes of address and reception.

\section{Arrested Motion: Domesticating the Moving Image in Early Film Theory}

The first cinematographic projections presented a new aesthetics of motion, which was also advertised as such by exhibitors. The German travelling cinema Ohr, for instance, called attention to its film screenings through a comparison with other moving-image devices in 1904: "what a difference between these primitive machines [referring to the zoetrope and the electrotachyscope] and the cinematograph! The extraordinary progress in the field of photography has made it possible for this machine to capture everything that plays out in front of the camera in the smallest conceivable partial motions."7 The passage suggests that the projected film image does not just transform individual bodies or clearly delineated objects into pronounced movements; rather, it sets everything in

$6 \quad$ For a similar perspective on these processes of adaptation see Curtis (2016).

7 Programme booklet of the Ohr travelling cinema, 1904, Nördlingen city archives (call number E IV 1, 6). 
motion. This alludes to an aesthetics of motion such as can be observed in many of the Lumières' early outdoor scenes, which show bathing people, arriving locomotives, or lively street traffic. These images seem to pulsate below the surface, so to speak, as if they were composed of a multitude of synchronous and interpenetrating micro-motions. ${ }^{8}$

To many contemporaries, the "life stirring thousandfold" in early film footage did not appear as the result of deliberate artistic creation, but as a merely technical reproduction of an external reality. As early as 1896, British journalist O. W. Winter thus wrote: "here, then, is life; life it must be because a machine knows not how to invent; but life which you may only contemplate through a mechanical medium" $(1996,14)$. This impression of "life," a trope in many comments of the time which would eventually lead to the notion of film as a "living picture," does not refer to a gentle animation emanating from within (as suggested by the Latin anima, which means soul, or breath). Rather, it means a technically reproduced exterior motion that is beyond the grasp of the human mind. As Winter writes: "we cannot follow the shadows in their enthusiasm of recognition" $(1996,14)$.

As it seemingly evaded any artistic shaping, cinematic motion offered an entry point for the unplanned, the unpredictable, and the contingent in the eyes of contemporaries (see Doane 2002, 137). ${ }^{10}$ In this regard, film was a visual manifestation of a loss of control, because it opened up the image - hitherto almost invariably seen as the result of an immobilizing human act of creation - to life, a life that, in modernity, was increasingly conceived of as constantly changing, contingent, mechanically induced, and therefore not fully controllable.

This new cinematic aesthetics of motion held a great fascination for many spectators and could thus also be employed in advertising. At the same time, it was obviously hard to reconcile with the traditional - and still dominant - bourgeois notion of beauty, which was inextricably linked to ideas of the meaningful and spiritual. While classical aesthetics did include the beauty of movement in the concept of grace, this referred to "willful movements [...] which express moral sentiment," that is, a meaningful emotional expression ultimately radiating from within (Schiller 1992, 339-349). But contingency as a visual effect, insistently

8 Explicit distinctions between the cinematograph and other moving image devices are common at the time. In 1896, for example, Uruguayan Luis Gonzaga Urbina speaks of a "liveliness that the kinetoscope lacks" (2008, 45). See also Gunning 2009.

9 Report on a film screening with footage of Geman Navy League boats, in Nördlinger Anzeigenblatt 65 (19 March 1906), 328.

10 While Doane conceives of contingency as a consequence of cinematic temporality primarily at the narrative level, it seems equally important to me to view it as a visual effect stemming from the mechanical reproduction of numerous small motions that are only minimally purposeful, if at all. 
asserting itself in the motion dynamics of early films, was diametrically opposed to the idea of the artist whose organizing hand creates beauty by consciously shaping reality. Beauty as an expression of meaning and order rather than of coincidence was still a theoretical premise of neo-Kantian thought in the early $20^{\text {th }}$ century, as emphasized by Georg Simmel in a 1903 essay on Kant: "art [...] organizes existence, until it displays the summariness, the inherent necessity, the suspension from the burden of coincidence, [...] insofar as the art work lets this form resonate into a subjective feeling, it also contains beauty" (Simmel 2008, 170).

As cinema became a part of visual culture that could no longer be ignored, it began to challenge the cultural leading role of fine art, especially in Germany. For a bourgeois audience that saw itself as a representative of this art sphere, film images must have seemed deeply unsettling. Of course, this also had to do with the fundamentally plebeian character associated with the new mass medium, with its sensationalist and supposedly vulgarizing subject matter that appealed to the "lower instincts." Yet, it was not least the motion of the images that constituted a provocation for an aesthetic sensibility schooled in contemplative art viewing. Often, commentators such as Max Bruns and Konrad Lange detected nothing but "horrible confusion" and "restlessness and blurriness" (Schweinitz 1992, 274; Lange 1912, 13). Nevertheless, reactions to the new "cultural factor" of cinema were quite diverse, even among the middle classes. Whereas a decidedly hostile attitude initially dominated in Germany, the 1910s saw the emergence of aesthetic concepts for a cinematic Volkskunst (popular art) that would be acceptable to bourgeois culture (see Schweinitz 1992, 9). Efforts of this kind were concentrated in the so-called Kinoreformbewegung (cinema reform movement), which sought to integrate cinema into the ranks of bourgeois cultural assets, and thus attacked the allegedly corrupting forms of popular film. This is also where the notion of beauty entered the scene, assuming the role of a virtual combat term against "immorality," "filth," and "tripe." Thus, cinema reformer Hermann Häfker claimed a "right to beauty" for the film-going public, "a right of the people and of youth [...] to be protected from ugly impressions that are offensive to the senses and damaging to health" (1907). This pedagogical impetus, here linked to the notion of beauty, was widespread in Germany. Karl Wilhelm Wolf-Czapek, for instance, wrote in his monograph Die Kinematographie: Wesen, Entstehung und Ziele des lebenden Bildes: "in the big catalogues, and sometimes also at screenings, one sees images of the kind that should be cultivated, capable of eliciting instruction, a pleasure in beauty, and the formation of taste" $(1908,102)$. However, to credibly reframe the film image as a signifier of beauty required 
a fundamentally different concept of cinematic motion, for which a potential aesthetic value had yet to be claimed. A comment by Georg Kleibömer from 1909 is symptomatic of this need for reinterpretation: "will the image really cease to be poetic, will it not become even more poetic when the whole image is set into motion, especially for those who are unaccustomed to the contemplation of artworks and lack imagination? [...] To my view it would indeed be possible to judge a moving image according to artistic principles like composition or execution" (Kleibömer 1909).

Reconciling cinematic motion with the laws of beauty demanded a normative aesthetics, which avoided the particularly disturbing forms of movement causing "horrible confusion," while emphasizing and welcoming others that were more easily adapted to traditional aesthetic concepts such as the composition mentioned by Kleibömer (see Wiegand 2018b). Around 1910, various authors thus began to conceive of the film image as "painting in motion." That is, while they recognized motion as a constitutive element of cinematic imagery, they conceptually related it to the stasis of painting, with all its attendant formal qualities and reception categories. In this regard, cinematic motion was no longer the disturbing Other, inevitably opposed to the artistically composed picture, but rather its gentle expansion. This expansion was not allowed to stray too far from painterly compositions, though, so that the static image and its status as the highest realization of artistic standards remained ultimately untouched. Accordingly, some writers in the German cinema debate called for more participation of fine artists and suggested bringing to life their paintings in film. As Gustav Taudien suggests: "let us have all the events that preceded the single moment captured by the painter actually play out before our eyes, with the famous picture by the respective painter as the worthy finale" (1913). ${ }^{11}$

In sum, the emerging film-theoretical discourse transferred the aesthetic category of beauty to the mass-cultural phenomenon of film by systematically distinguishing "good" and "bad" kinds of cinematic motion, thereby conceptually subjecting it to a tendency towards stasis. Structurally, these authors demanded something that had already been realized practically in previous years, namely in the static and beautiful displays of tableaux vivants.

11 In early film history, the idea of "realizing" paintings in films is frequently expressed and also put into practice (see Robert 2018). On the German debate about the involvement of painters in film production see Diederichs 2001, 76-78. 


\section{Arrested Beauty: Tableaux Vivants in Variety Theatre}

When calling for more cinematic beauty, Wolf-Czapek compares cinema's role in society to that of the established institution of variety theatre, which is "to be a stage for physical beauty and physical strength, for colour- and light-suffused joyous art" $(1908,101)$. The author thus draws on a bourgeois discourse of reform that began in the late $19^{\text {th }}$ century with the emergence of the big variety stages - which addressed a highbrow bourgeois audience - and explicitly applies this discourse to the incipient efforts to reform cinema. The older debate, conducted primarily in the German variety trade press, was still current at the outset of the new reform movement aimed at cinema, and it included several authors who also wrote about film (e.g. Oscar Geller and A. Günsberg). Like the cinema reformers, the variety reformers were concerned with elevating forms of entertainment that originated among and addressed the lower classes - such as circus shows - in order to lend them a semblance of art for middle-class audiences.

With growing economic dominance, the middle classes had become increasingly interested in popular culture during the late $19^{\text {th }}$ century, while simultaneously looking for ways to dissociate themselves from forms of "low," seemingly plebeian entertainment. They were thus open to adapting the respective phenomena to fit their own understanding of art and beauty (see Maase 1997, 103-107). Accordingly, the efforts of German variety reformers to designate circus acts as art became condensed in the notion of "beauty" and in the core idea of an "increasingly perfected aesthetics" (Günsberg 1903). Like the later debate on cinema, this discussion often focused on visual aspects. In variety theatre, this primarily concerned the performers' shapely bodies, their elegant movements, and the design of the stage with the help of lighting and décor. The purported link to the traditional arts was supposed to manifest itself in the aesthetic qualities of the performances as well as in the increasingly splendid architecture of the variety palaces.

In the course of these efforts, no other kind of act was mentioned as often and as unquestioningly as that of tableaux vivants, that is, "the representation of works of painting and sculpture by living persons" (Brockhaus 1902, 1029). In addition to animal acts, songs, comedy, and various circus acts, tableaux vivants were a staple in the diverse repertoire of the variety stages, and they remained hugely popular well into the $20^{\text {th }}$ century. Tableaux vivants were presented either by individual performers [Fig. 1], by small groups of two to four [Fig. 2], or by larger ensembles; in the latter case they usually operated under the name of the artistic 
director, presenting spectacular "mass pictures" (Massenbilder). Sometimes, they re-enacted paintings - with painted backgrounds and a picture frame to create a surface impression -, sometimes freestanding sculptures.

For reformers such as A. Günsberg, the "aesthetic aspect" (1906) that should be a mark of all variety acts found its most complete expression in tableaux vivants. They offered a convincing argument for variety theatre as a site of art and beauty because their origins were not in travelling circus shows, but in highbrow theatre and in the aristocratic and upper-middle-class salons of the late $18^{\text {th }}$ and early $19^{\text {th }}$ centuries. Integrated into a sophisticated culture of parlour games and theatricals (which also included charades and masquerades), they were aimed at the acquisition of "good taste" and the constitution of an educated elite, with the re-enacted images belonging to an authoritative canon of art history, which the performers literally incorporated (see Jooss 1999). Even when tableaux vivants became a widespread attraction of popular culture over the course of the $19^{\text {th }}$ century - appearing on fairgrounds, in circuses, and in light theatre - they never fully shed their connotations of the artistic, contemplative, and sophisticated. One reason for this was their subject matter: even in these popular contexts, the tableaux re-enacted paintings and sculptures from the sphere of classical, neoclassicist, and contemporary academic art. Henry de Vry's Gallery of Living Pictures, for example, performed at Berlin's Wintergarten in 1894, presented works of then-current representatives of the German and French art academies such as Hermann von Kaulbach and Émile Bayard in addition to neoclassicist sculptures and the Venus de Milo. ${ }^{12}$ The names of the fine artists were printed on the playbill, which shows how explicitly a popular attraction adorned itself with the insignia and prestige of "true" art in order to address an educated and art-oriented audience familiar with these names and titles, thus giving them an incentive to see the show. Even when tableaux vivants didn't represent specific works - so-called free compositions became increasingly popular in the early $20^{\text {th }}$ century - they were stylistically informed by the artistic taste prescribed by the academies, which pervaded bourgeois cultural life. The similarities can be seen when comparing a work re-enacted by de Vry in 1894 - Glaube, Liebe, Hoffnung (Faith, Love, Hope) by Austrian court painter Josef Arpad Koppay with the photograph of a tableau vivant by de Vry that had no specific model: both consist of a frontal - or at least unhindered - view of shapely bodies seen in their entirety, clearly standing out against a simply designed background in a balanced overall composition. [Figs. 3-4.]

12 Playbill of the Berlin Wintergarten theatre, Berlin City Museum. 
Furthermore, tableaux vivants were especially suited to draw on notions of beauty from classical aesthetics because - like paintings and sculptures - they presented static images. Although the variety reformers also tried to develop conceptions of beauty for more movement-oriented performances by describing their "harmoniousness of movement" and "artistic elegance" (Kurz-Elsheim 1904; see also Lasker 1904), the completely arrested bodies of tableaux vivants offered a conceptual reference point of artistic contemplation in which ideas of the aesthetic image culminated, as it were. Thus, even when they didn't adopt specific motifs, tableaux vivants lent themselves to established conventions of picture composition and art contemplation more easily than other types of popular performance. Advertisements accordingly emphasized the "grace of lines and of the composition in general" and the "pleasure of graceful lines." 13 The arresting of living bodies into static images, constitutive of tableaux vivants, can be seen as an emphatic display of the aesthetic aspect in variety theatre and as a radical capture of the potentially ugly performing body. As if to emphasize this point, British journalist W. T. Stead described Pansy Montague's popular tableaux vivants as a kind of immobilized island of beauty amid an otherwise crudely grotesque programme: "each tableau formed an exceedingly beautiful picture, upon which the eye, fatigued with the endless procession of grotesque and ugly and garish figures, dwelt restfully and lovingly. It was a glimpse of the clear blue sky, or of the midnight heaven radiant with stars" (Stead 1906).

\section{Tableaux Vivants as an "Attractional Dispositif” and Beauty-as-Attraction}

Although tableaux vivants pointedly referenced the tradition of art and the aesthetic canon of bourgeois culture, they were simultaneously a visual attraction appealing to the Schaulust of an urban and potentially multi-class mass audience. In this regard, they followed the same dynamics of novelty and spectacle as any other kind of variety act. They were advertised as an "unparalleled boxoffice draw" and "first-rate attraction." As I argue more thoroughly elsewhere (Wiegand 2016 and 2018a), the attraction consisted in the display of well-shaped (often scantily-clad or naked) bodies, and in impressive body control, which allowed for the near-complete illusion of lifelessness. Furthermore, tableaux

13 Leipziger General-Anzeiger, quoted from an advertisement for the Mimiplastika Pygmalion Gallery, in Das Programm 9 (1902), n.p.; Advertisement for Henry de Vry, in Das Programm vol. 626 (1914), n.p. 
vivants constituted an astonishing and decidedly modern technology of image production. Along with serpentine dances, illuminated water fountains, and screen projections (such as magic lanterns and films), they belonged to the socalled dark acts (Dunkelnummern), for which the auditorium lights were dimmed to show off special light effects (de Vry 1909). Starting around 1890, this included - inherently modern - electric lights. To use an apt term by Frank Kessler (which he employs in relation to early cinema), the tableaux vivants of the variety stages thus functioned as an "attractional dispositif" (2006). The technical apparatus and the viewing situation in which the pictures were presented made them visual attractions. The darkening of the auditorium, the lighting of the stage, and possibly also the suspense created by the opening curtain served to focus the spectators' attention and captivate their gaze. Even the lighting was an attraction in itself while simultaneously transforming the bodies on stage into a potentially dematerialized image to be looked at (see Faulk 2004, 142-187).

Thus, at the intersection of sensational light design and aesthetic picture composition, tableaux vivants addressed their audience both with the lure of the latest attraction and with the promise of beauty, art, and sophistication. The result was a kind of overlap between the aesthetics of attraction and classical aesthetics at three different levels - the rhetorical-discursive level, the level of picture composition, and the level of reception.

At the rhetorical-discursive level, advertisements in variety periodicals alternately emphasized the sensational aspect and the artistic value of the numbers. Often, these two rhetorical strategies were interlaced, as in a promotional text for the group Les Olympias [Fig. 2]: "until now, these poses have only been presented in white (marble) or gold (bronze). As a novelty, Les Olympias bring vivid poses in patina (old bronze). The green hue of antique bronze has a soothing effect on the eye, does not blind it and - making the poses stand out ever more vividly offers the viewers true artistic pleasure." ${ }^{14}$ What is announced as a sensational novelty is simultaneously meant to enable artistic pleasure. The introduction of the new hue is thus the logical consequence of a sensationalist consumer culture always aiming for novelty, but also the result of a competent aesthetic judgment, intended for contemplation.

In terms of picture composition, many of the paintings that typically served as models for tableaux vivants already contained a certain attraction potential with bodies frontally presenting themselves to the viewer's gaze - which readily lent itself to the stage context. At the same time, the paintings' emphasis on

14 Advertisement in Das Programm vol. 231 (1906), n.p.; original emphasis. 
compositional harmony and balance in the distribution of lines, surfaces, and colours corresponded to classical aesthetics. By imitating such art works, tableaux vivants preserved their qualities, but also modelled them into components of an "attractional dispositif" through immediate physical display and spectacular lighting effects.

Finally, the overlap described above constitutes a phenomenon of reception. The cited advertisement assumes an audience equally interested in spectacular variety attractions and in art, indeed, an audience for whom the elaborate presentation of the most recent art works itself is an attraction. Similarly, the playbill for de Vry's Gallery of Living Pictures implies an audience familiar with the bourgeois cultural technique of art contemplation (thus the mention of painting titles and artist names), while also marvelling at the modern "lighting effects and the apparatus with which the images are transformed." ${ }^{15}$ For the type of spectator addressed, then, a desire for art appreciation and an appetite for new visual sensations pervaded each other.

I propose the term "beauty-as-attraction" to describe this specific mode of address, which pitched tableaux vivants as spectacular attractions and simultaneously pointed to their beauty and their connection to the traditional arts. In terms of reception, this mode can be linked to a certain Schaulust, albeit of a tamed kind that was less about erotic allure, violence, or thrill, and more about the visual enjoyment of colours, lights, and shapes. ${ }^{16}$ These elements were designed so as to constantly surprise and overwhelm the sense of vision (in the vein of an attraction), while simultaneously relating to classical aesthetics, a traditional iconographic repertoire, and established categories of art reception.

\section{Beauty-as-Attraction in Film}

Film drew on the performance practices of tableaux vivants early on, thus transferring beauty-as-attraction to a new media context. Among the earliest examples are several series of productions by the American Mutoscope and Biograph Company, either made or re-released in new compilations between 1897 and 1903. [Fig. 5.] The Biograph Picture Catalog highlighted these films separately within the genre label of vaudeville views and linked them to the

15 This phrase from de Vry's playbill possibly refers to a revolving stage mechanism.

16 In his 1913 article Cinema and Visual Pleasure (Kino und Schaulust), later Dadaist Walter Serner disdainfully wrote about the "thickly powdered and besmeared nude bodies" $(2016,43)$ of tableaux vivants as an example of what he termed the "harmless variety" of Schaulust (2016, 42 ) as opposed to the true and cruel Schaulust in cinema $(2016,210)$. 
idea of an artistic refinement of the film image: "we call particular attention to our series of living pictures which were put on with as great care as to models, costumes, pose and properties as any of the largest productions of this order. They are excellent photographically, and of the highest grade pictorially." ${ }^{17}$

Many of the French and German productions advertised as films artistiques or Kunstfilms around 1910 also drew on the performance practices of tableaux vivants as seen on the variety stages at the time. Examples include Les heures and Le printemps (1909), two phonoscènes ${ }^{18}$ by director Louis Feuillade, who would release a whole production series for Gaumont under the title Le Film Esthétique (The Aesthetic Film) only a year later. ${ }^{19}$ Both films presented a thematically but not narratively motivated sequence of shots, showing female bodies arranged into picturesque groups with obvious references to antique art and mythology. ${ }^{20}$ Le printemps begins by showing a field and a frozen spring; through a dissolve, the water is transformed into a spluttering spring and a woman in a white gown appears above it, lying motionless for about seven seconds like in a tableau vivant, before she slowly moves her arms and plays with the white birds fluttering around. [Fig. 6.] Soon afterwards, two children enter the scene and also start playing with the birds, while the basic image composition remains the same. All the other shots follow a similar pattern: the figures appear as if retrospectively inserted into preexisting, static, and picturesque compositions of flowers, trees, and bodies of water, sometimes within round or oval frames; their movements are either markedly slow or dance-like. [Fig. 7.] The film is strikingly similar to certain tableaux vivants staged by Henry de Vry, for instance his Phantasmagorien, Traumbilder (dream images), or his Schäferspiel (pastoral) entitled Johannisnacht. These performances also presented images of female bodies on (artificial) fields and meadows, with lighting effects that lent them a magical quality. The Traumbilder were described as follows: "flocks of fluttering butterflies animate the scene, and floating groups of superbly beautiful girls (8 people) conjure up the most beautiful feast for the eyes in dreamy light effects. An entire fairy world is created: mermaids, nymphs, elves, mythological goddesses, shepherdesses with a large grazing herd, partly

17 Biograph Picture Catalog 1902, 54. It should be added that these films oscillated between the conflicting tendencies of artistic ennoblement and erotic display; see Wiegand 2016.

18 Phonoscènes were films distributed together with music recorded on sound discs.

19 The publicity text for this series, written in the style of a manifesto, called for the "beauty of ideas and beauty of form" as guiding principles (Feuillade 1910).

20 To the best of my knowledge, no copy of Les heures survives, but there are a number of historic publicity posters, advertisements, and programme notes (see e.g. Ciné-journal no. 27 [1909], n.p.; Der Kinematograph no. 117 [1909], n.p.; Die Lichtbild-Bühne no. 42 [1909], Die LichtbildBühne no. 58 [1909], n.p.). 
in brightest sunlight, partly in moonlight never before seen in such an effect. A magically beautiful allegory crowns the ending." ${ }^{21}$ Le printemps and de Vry's stage performance thus share the references to mythological imagery and the interweaving of physical and natural beauty through aestheticizing light effects and colours. While de Vry's tableaux vivants employed coloured lights, films like Le printemps brought the luminous appearances to the screen with the help of the projector light and coloured film stock. ${ }^{22}$

In 1909, Émile Cohl also made some films for Gaumont using tableaux vivants. L'éventail animé begins with a screen-filling frontal view of a folded fan, which soon opens up as if by magic. Through a dissolve, women appear on the individual fan leaves, each holding another fan in their hands. [Fig. 8.] While the film shows the magical coming-to-life of a fan by way of cinematic tricks, the focus seems to be more on the resulting splendorous ornamentation of the image: the symmetrical composition of female poses presents itself to the audience's gaze for several seconds without further changes through additional tricks. Accordingly, the American publicity for the film by the George Kleine Optical Company points out the impression of beauty evoked by the fan: "a delightfully pleasing and beautifully hand-colored series of panoramic views [...]. A large ostrich feather fan opens alternately showing each time a different scene." "23 Ornamental "living fans" were a common type of tableaux-vivants act on variety stages. In 1904, tableaux-vivants director Dr. Angelo appeared at Berlin's Wintergarten theatre with the number Der lebende Fächer in Watteau Manier ${ }^{24}$ (The Living Fan in the Manner of Watteau), and in addition to the main attraction, he also showed "wonderful living porcelain imitations in the style of Sèvres and Meißen, Majolica reliefs, and other creations in the field of mechanics." 25 [Fig. 9.]

In L'éventail animé, the living fan is the prelude to a series of six short scenes, which illustrate the use of fans in well-known historic situations. [Fig. 10.] By framing the individual shots with the contours of a giant fan (similar to the circles and ovals in Le printemps), the ornamentation from the first shot is carried over into the rest of the film. At the same time, the frame marks a proscenium and thus introduces another level of representation, making the figures seem as if arranged on a stage rather than appearing in a film. Even if they don't keep completely still, the staging of the scenes is obviously reminiscent of tableaux

21 Vom Berufsleben, in Das Organ vol. 246 (1913), 10.

22 Unfortunately, the surviving copy of the film does not contain the original colouring.

23 Moving Picture World vol. 4/23 (1909), 744.

24 In the $19^{\text {th }}$ century, fans with motifs by French painter Jean-Antoine Watteau were popular.

Moderne Kunst (monthly edition) XIX/11 (1904/05), 267. 
vivants: the conspicuous parallel staging without any background, the bodies' mostly frontal positioning towards the viewer, the overall preservation of poses despite some movement, and finally, the limited dramatic development and reduction to specific representative moments. The film's serial structure, with individual episodes exemplifying the same basic idea (in this case, the fan as a historic leitmotif) also resembles the performance structure of many tableaux vivants. L'éventail animé almost ideally fulfils what authors such as Wolf-Czapek demanded for film at the time, namely "the clear side-by-side of persons and objects," the "avoidance of hasty movement," and "that the figures be clearly delineated against the background everywhere in the image" (1910, n.p.).

In other films, the figures are in a complete standstill, at least for a while. Porcelaines tendres (Émile Cohl, 1909) consists of four shots, each presenting a short dance number. Before each dance, the performers stand still for several seconds, while imitating decorative objects that contain porcelain figurines. Such imitations were extremely popular on the variety stages in 1909 (see Hellwig 1909). In the first shot entitled La coupe grecque (Greek bowl), two performers form the bowl's ornamented shaft, with the lower and upper parts represented by painted decorations. The bowl, frontally and centrally positioned, is enclosed by an adorned frame, producing an overall impression of a symmetrically arranged ornament. [Fig. 11.] The neat composition and the dark background, against which the individual elements clearly stand out, create an impression of pictorial coherence and unity. After about ten seconds of complete stasis, the bowl is slowly lifted before the two dancers gradually start moving, climbing down from their pedestal, yet without completely abandoning their poses. While one of them eventually goes into dance movement - which nevertheless resembles a series of pictorial moments - the other sits down on the pedestal in a completely static pose. The shot ends with the dancer also assuming a static pose next to the other performer.

\section{Conclusion}

In many ways, tableaux-vivants performances around 1900 corresponded to popular middle-class ideas about art and the contemplation of beauty. At the same time, with their overt display of luminous and spectacular body images, they constituted an "attractional dispositif." For the operators of the big variety theatres, they thus fulfilled two objectives simultaneously: to offer new visual sensations and to present "art" to a bourgeois audience. By transferring the performance modes and visual motifs of tableaux vivants to film, this twofold 
address of beauty-as-attraction was brought to fruition in the new context of film screenings. Like the respective live performances, films such as Le printemps and Porcelaines tendres presented shapely bodies frontally facing viewers, turning them into displays of visual attractions through technological transformation while nevertheless preserving a connection to fine art in terms of their composition and content. The successful shift from variety number to cinematic motif was aided by the conspicuous similarities between cinema and the staging of tableaux vivants as dark acts. In both cases, the audience's attention was directed to a succession of potentially dematerialized and often colourful images of light.

Both the mode of address and the film-theoretical discourse outlined above can be read as an expression of a changing visual culture around 1900, when the emerging mass media entered into diverse and sometimes contradictory symbiotic relationships with the established arts. Within these cultural negotiations, the aspect of immobilization significantly influenced the period's theoretical discourses and aesthetic practices as a figure of thought and creative strategy. It structured notions of beauty in film - for instance in the writings of the cinema reformers - as well as the process of image-creation in tableaux vivants (on stage and screen). It was only in the modes of stasis and near-stasis, it seems, that attempts to reconcile traditional aesthetics with the dawning of media modernity succeeded to some extent.

In the films analysed here, the tendency to partially or temporarily arrest the moving image produced harmonious and well-structured compositions. This trend of immobilizing images simultaneously appeared in the emerging fiction film. Certain moments in the plot become condensed into visual stops within the films' narrative flow when hitherto mobile configurations of characters freeze for an instant, presenting orderly, memorable, and momentous compositions, which often also reference well-known paintings (see e.g. Brewster and Jacobs 1997; Blom 2001; Askari 2014). However, what is interesting about the films discussed here is that they do not resort to tableaux vivants within a narrative context; instead, they display stasis as a visual attraction. In addition to adopting the structural moment of arrest and the motifs from fine art, they directly reference the tableaux-vivants attractions of variety theatre.

The developments outlined here are characterized by a certain ambivalence. On the one hand, they can be seen as a conservative reaction to new forms of visual media such as film, which shook the foundations of accepted aesthetic principles and hierarchies. On the other hand, as shown above, these "conservative" tendencies were inherently contradictory as they often united divergent notions of the aesthetic. Thus, the discourse on film as "painting in motion" simultaneously 
reflected the need for resorting to familiar categories of classical aesthetics and the educated middle classes' hesitant acceptance of media modernity. In other words, classical image composition and the attractions of modern visual media overlapped in the mode of beauty-as-attraction, which was therefore especially successful in the new medium of film. Rather than simply imposing an antiquated notion of beauty on the films discussed here, this mode allowed them to express a complex layering of varied and partly contradictory aesthetic ideas.

However, to many advocates of art and aesthetics, films such as Porcelaines tendres might very well have represented a tendency towards banalization, in the sense of reducing the artistic to something merely pretty, decorative, or even kitschy - a tendency that would occasion its own defence mechanisms over the course of film history (see Galt 2011). Many contributions to the classical film theory of the 1920s and 1930s - especially the writings of Béla Balázs and Jean Epstein - turned decidedly against the picturesque, decorative, stylized, and arrested elements in film, often condescendingly labelling respective scenes as tableaux vivants (see Epstein 1988, 246; Balázs 2010, 42). Conversely, these authors emphasized the cinematic qualities that had already appeared in the earliest film discourses around 1900, but were "suppressed" by the reformist theorists. These very qualities - elusiveness and coincidence, for example - were now being linked to the concept of beauty (see Delluc 1986, 31). ${ }^{26}$

Throughout the history of film and film theory, notions of beauty thus seem to alternately crystallize around and distance themselves from similar creative principles and theoretical ideas. Beauty as a visual quality that is characteristic of static and harmoniously composed images, and which had therefore already reached its peak in painting, is one such insistently repeated topos - whether formulaically invoked in journalistic film criticism to this day or, conversely, raised as the spectre of a theoretical stance according to which the fluid and shifting character of cinematic experience is the epitome of beauty.

(Translated from German by Susie Trenka.)

26 In Pretty (2011), Rosalind Galt traces a continuous line from Kant's classic-idealist aesthetics to the film theory of André Bazin in the 1950s, a connection expressed in the appreciation of the "valuable" and the corresponding devaluation of the pretty as that which is only superficially beautiful. To my mind, this needs to be qualified insofar as most of the classic film theorists did not reject the pretty or decorative in film simply because they saw themselves as defenders of idealist aesthetics and as opponents of art's alleged trivialization. Rather, they viewed the unreflecting appropriation of fine art by film overall as an illegitimate and doomed undertaking, because for them, it suppressed what was felt to be revolutionary and new in cinematic aesthetics (expressed in terms such as Delluc's photogénie). 


\section{References}

Askari, Kaveh. 2014. Making Movies into Art: Picture Craft from the Magic Lantern to Early Hollywood. London: Palgrave Macmillan.

Balázs, Béla. 2010 [1924/1930]. Early Film Theory: Visible Man and the Spirit of Film. Oxford, New York: Berghahn.

Blom, Ivo. 2001. Quo Vadis? From Painting to Cinema and Everything in Between. In La decima musa: Il cinema e le altre arti [The Tenth Muse: Cinema and other Arts], eds. Leonardo Quaresima and Laura Vichi, 281-292. Udine: Forum.

Bottomore, Stephen. 1996. 'Nine Days' Wonder': Early Cinema and its Sceptics. In Cinema: the Beginnings and the Future, ed. Christopher Williams, 135-149. London: University of Westminster Press.

Brewster, Ben and Lea Jacobs. 1997. Theatre to Cinema: Stage Pictorialism and the Early Feature Film. Oxford, New York: Oxford University Press.

Brockhaus Konversations-Lexikon. 1902. Vol. 10. Leipzig, Berlin, Wien: Brockhaus Verlag.

Curtis, Scott. 2015. The Shape of Spectatorship: Art, Science, and Early Cinema in Germany. New York: Columbia University Press.

De Vry, Henry. 1909. Dunkelnummern: eine fachtechnische Plauderei [Dark Acts: a Technical Talk]. Das Organ vol. 48: 6-8.

Delluc, Louis. 1988 [1917]. Beauty in the Cinema. In French Film Theory and Criticism: A History. Anthology 1907-1939. Vol. I: 1907-1929, ed. Richard Abel, 137-139. Princeton, New Jersey: Princeton University Press.

Diederichs, Helmut H. 2001. Frühgeschichte deutscher Filmtheorie. Ihre Entstehung und Entwicklung bis zum Ersten Weltkrieg [History of Early German Film Theory until WWI]. http://publikationen.ub.uni-frankfurt.de/frontdoor/index/index/docId/4924. Last accessed 11. 09. 2018.

Diederichs, Helmut H., ed. 2004. Geschichte der Filmtheorie. Kunsttheoretische Texte von Méliès bis Arnheim [History of Film Theory: Art Theoretical Texts from Méliès to Arnheim]. Frankfurt a. M.: Suhrkamp.

Doane, Mary Ann. 2002. The Emergence of Cinematic Time: Modernity, Contingency, the Archive. Cambridge, MA, London: Harvard University Press. Epstein, Jean. 1986 [1921]. The Senses I (b). In French Film Theory and Criticism: A History/Anthology 1907-1939. Vol. I: 1907-1929, ed. Richard Abel, 241-246. Princeton, New Jersey: Princeton University Press. 
Faulk, Barry, J. 2004. Music Hall and Modernity: The Late-Victorian Discovery of Popular Culture. Athens: Ohio University Press.

Feuillade, Louis. 1910. Le Film Esthétique [The Aesthetic Film]. Ciné-journal vol. 92: 19.

Galt, Rosalind. 2011. Pretty: Film and the Decorative Image. New York: Columbia University Press.

Gonzaga Urbina, Luis. 2008 [1896]. Le Cinématographe [The Cinematograph]. In Le cinéma: naissance d'un art 1895-1920 [The Cinema: Birth of an Art], eds. Daniel Banda and José Moure, 44-47. Paris: Flammarion.

Gunning, Tom. 1986. The Cinema of Attractions: Early Film, Its Spectators and the Avant-Garde. Wide Angle no. 8: 63-70.

Gunning, Tom. 1995 [1989]. An Aesthetic of Astonishment: Early Film and the (In)Credulous Spectator. In Viewing Positions: Ways of Seeing Film, ed. Linda Williams, 114-133. New Brunswick, New Jersey: Rutgers University Press.

Gunning, Tom. 2009. The Attraction of Motion: Modern Representation and the Image of Movement. In Film 1900: Technology, Perception, Culture, eds. Annemone Ligensa and Klaus Kreimeier, 165-173. New Barnet: John Libbey.

Günsberg, A. 1903. Aesthetik bei Variété-Darbietungen [Aesthetics in Variety Shows]. Das Programm no. 79: n.p.

Günsberg, A. 1906. Psychologische Wirkungen von Schaunummern [Psychological Effects of Show Acts]. Der Artist no. 1140: n.p.

Häfker, Hermann. 1907. Das Recht auf Schönheit [The Right for Beauty]. Der Kinematograph no. 41: n.p.

Hellwig, A. [Albert?]. 1909. Lebende Bilder einst und jetzt [Living Pictures Then and Now]. Das Organ no. 19: 1-2.

Jooss, Birgit. 1999. Lebende Bilder: Körperliche Nachahmungen von Kunstwerken in der Goethezeit [Living Pictures: Corporeal Imitations of Artworks in Goethe's Era]. Berlin: Dietrich Reimer.

Kaes, Anton, Nicholas Baer and Michael Cowan, eds. 2016. The Promise of Cinema: German Film Theory 1907-1933. Oakland: University of California Press.

Kessler, Frank. 2006. The Cinema of Attractions as Dispositif. In The Cinema of Attractions Reloaded, ed. Wanda Strauven, 57-69. Amsterdam: Amsterdam University Press.

Kleibömer, Georg. 1909. Kinematograph und Grammophon im Dienste der Kunst [Cinematograph and Grammophone in the Service of Art]. Der Kinematograph no. 127: n.p. 
Kurz-Elsheim, Franz. 1904. Variété und Kunst [Variety Theater and Art]. Der Artist no. 1022: n.p.

Lange, Konrad. 1912. Der Kinematograph vom ästhetischen Standpunkt [The Cinematograph from an Aesthetic Viewpoint]. In Der Kinematograph als Volksunterhaltungsmittel, 100. Flugschrift des Dürerbundes zur Ausdruckskultur [The Cinematograph as Popular Entertainment], ed. Robert Gaupp and Konrad Lange, 12-50. München: Dürerbund.

Lasker, Franz. 1904. Zur Aesthetik der Circus-Kostüme [On the Aesthetics of Circus Costumes]. Der Artist no. 1025: n.p.

Maase, Kaspar. 1997. Grenzenloses Vergnügen. Der Aufstieg der Massenkultur 1850-1970 [Pleasure without Boundaries: The Rise of Mass Culture]. Frankfurt a. M.: Fischer.

Musser, Charles. 2006. A Cinema of Contemplation, a Cinema of Discernment: Spectatorship, Intertextuality and Attractions in the 1890s. In The Cinema of Attractions Reloaded, ed. Wanda Strauven, 159-179. Amsterdam: Amsterdam University Press.

Robert, Valentine. 2018. Early Cinema's Realizations: The Pictorial in the Tableau Style. In The Image in Early Cinema: Form and Material, eds. Scott Curtis, Philippe Gauthier, Tom Gunning and Joshua Yumibe, 289-299. Bloomington: Indiana University Press.

Runge, Jörn E. 2009. Olga Desmond: Preußens nackte Venus [Prussia’s Naked Venus]. Friedland: Steffen.

Schiller, Friedrich. 1992 [1793]. On Grace and Dignity. http://www.schillerinstitute. org/educ/aesthetics/Schiller_On_Grace_and_Dignity.pdf. Last accessed 11. 09. 2018.

Schwartz, Vanessa R. 1995. Cinematic Spectatorship before the Apparatus: The Public Taste for Reality in Fin-de-Siècle Paris. In Cinema and the Invention of Modern Life, eds. Vanessa Schwartz and Leo Charney, 297-319. Berkeley, Los Angeles, London: University of California Press.

Schweinitz, Jörg, ed. 1992. Prolog vor dem Film: Nachdenken über ein neues Medium [Prologue before the Film: Thinking about a New Medium]. Leipzig: Reclam.

Serner, Walter. 2016 [1913]. Cinema and Visual Pleasure. In The Promise of Cinema: German Film Theory 1907-1933, eds. Anton Kaes, Nicholas Baer and Michael Cowan, 41-35. Oakland: University of California Press.

Simmel, Georg. 2008 [1903]. Kant und die moderne Ästhetik [Kant and Modern Aesthetics]. In Jenseits der Schönheit. Schriften zur Ästhetik und 
Kunstphilosophie [Beyond Beauty: Writings on Aesthetics and the Philosophy of Art], ed. Ingo Meyer, 163-178. Frankfurt a. M.: Suhrkamp.

Stead, W. T. 1906. Notes from London. Der Artist no. 1128: n.p.

Taudien, Gustav. 1913. Maler heraus! [Painters Come Out!]. Der Kinematograph no. 34: n.p.

Wiegand, Daniel. 2016. Gebannte Bewegung: Tableaux vivants und früher Film in der Kultur der Moderne [Captured Motion: Tableaux Vivants and Early Cinema in the Culture of Modernity]. Marburg: Schüren.

Wiegand, Daniel. 2018a. The Unsettling of Vision: Tableaux Vivants, Early Cinema, and Optical Illusions. In The Image in Early Cinema: Form and Material, eds. Scott Curtis, Philippe Gauthier, Tom Gunning and Joshua Yumibe, 26-35. Bloomington: Indiana University Press.

Wiegand, Daniel. 2018b. Taming Motion: On a Certain Tendency in Early Film Theoretical Writing. In A Treasure Trove: Friend of the Photoplay - Visionary - Spy? New Trans-disciplinary Approaches to Hugo Münsterberg's Life and Oeuvre, ed. Rüdiger Steinmetz, 61-69. Leipzig: Universitätsverlag.

Winter, O. 1996 [1896]. Life is a Game According to a Set of Rules. In In the Kingdom of Shadows: A Companion to Early Cinema, eds. Colin Harding and Simon Popple, 13-17. London: Cygnus Arts Press.

Wolf-Czapek, Karl Wilhelm. 1908. Die Kinematographie: Wesen, Entstehung und Ziele des lebenden Bildes [The Cinema: Essence, Origins and Goals of the Living Picture]. Dresden: Union Deutsche Verlagsgesellschaft.

Wolf-Czapek, Karl Wilhelm. 1910. Ueber den Stil des Kunstfilms [On the Style of the Artistic Movie]. Der Kinematograph no. 189: n.p. 


\section{List of Figures}

Figure 1. Undated photograph of tableaux vivants performer Kitty (and dog); courtesy of Stadtmuseum Berlin (reproduction: Friedhelm Hoffmann, Berlin). Figure 2. Full page advertisement for the tableaux vivants group 3 Olympier in Das Programm no. 182 (1905); courtesy of Stadtmuseum Berlin (reproduction: Friedhelm Hoffmann, Berlin).
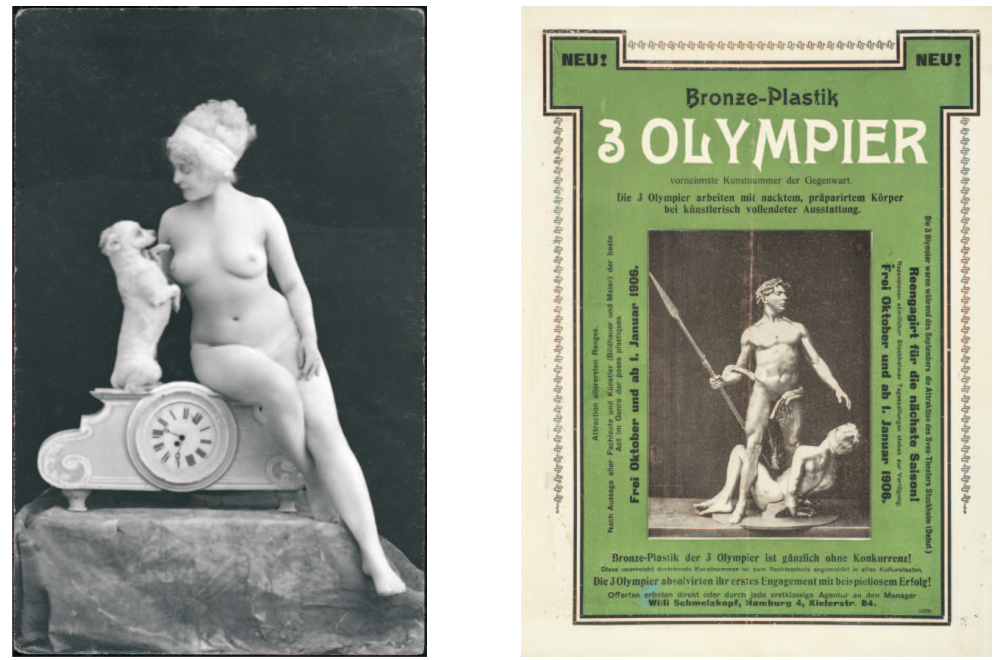

Figure 3. Josef Arpad Koppay: Glaube, Liebe, Hoffnung (1894), reproduction for a picture postcard. Figure 4. Detail of a picture postcard with a tableau vivant by Henry de Vry (c. 1900).
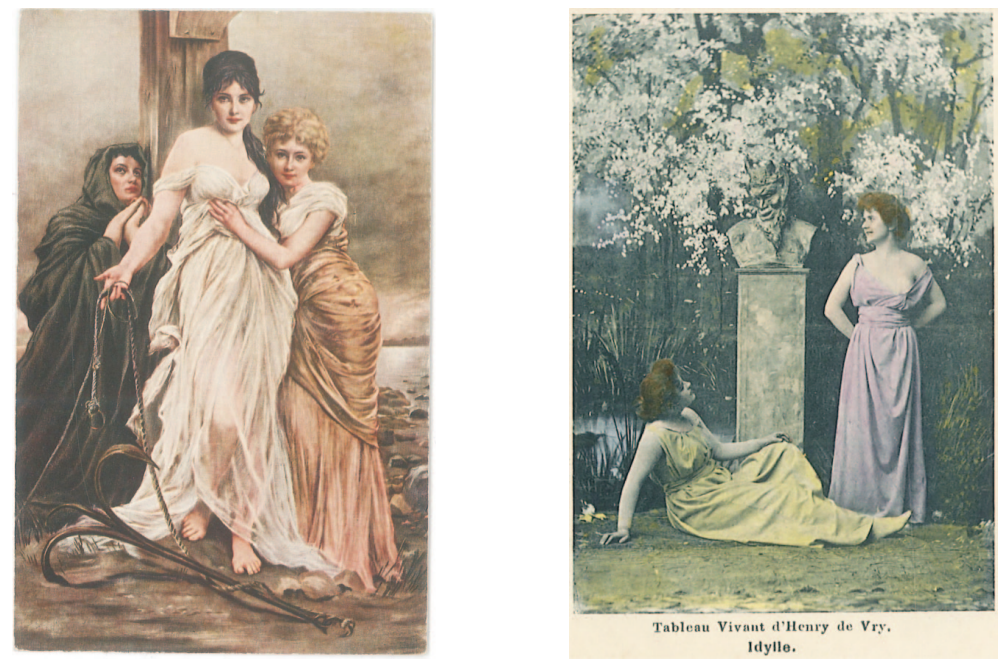
Figure 5. By the Sea, from the compilation Living Pictures (American Mutoscope and Biograph Company, USA 1903); courtesy of Library of Congress.

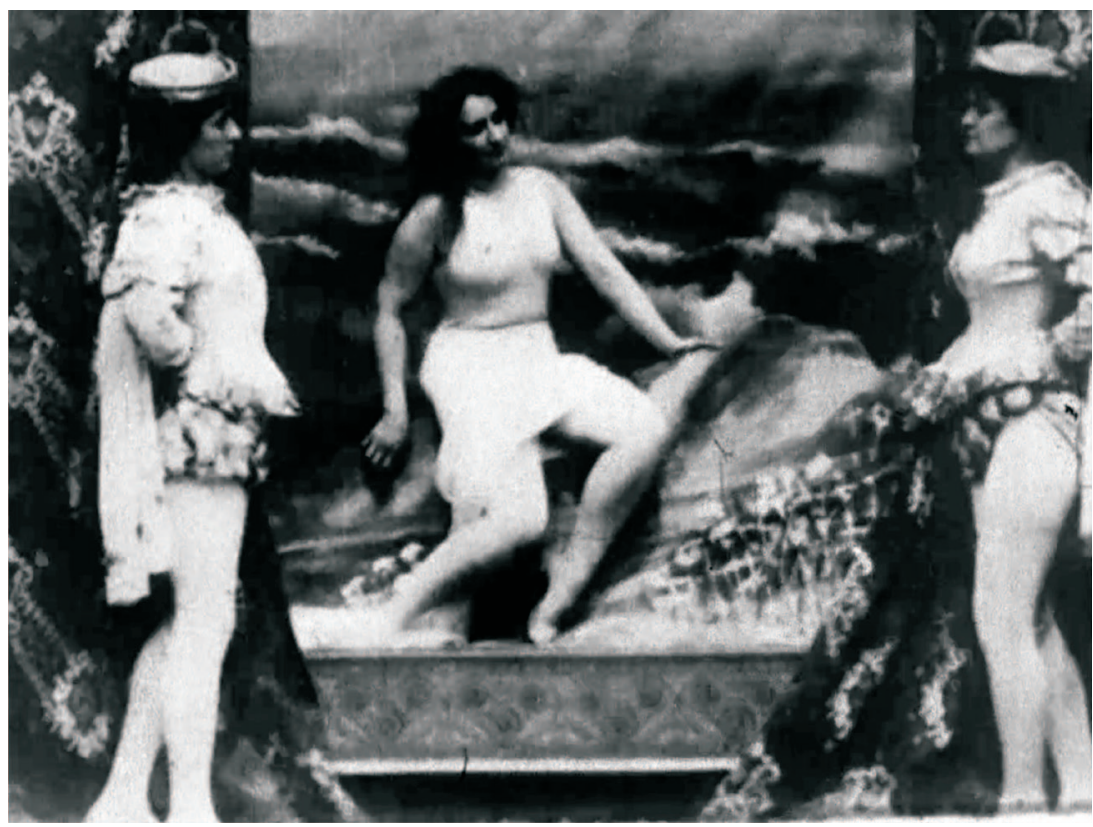

Figures 6-7. Le printemps (Louis Feuillade, F 1909, (c) Gaumont).

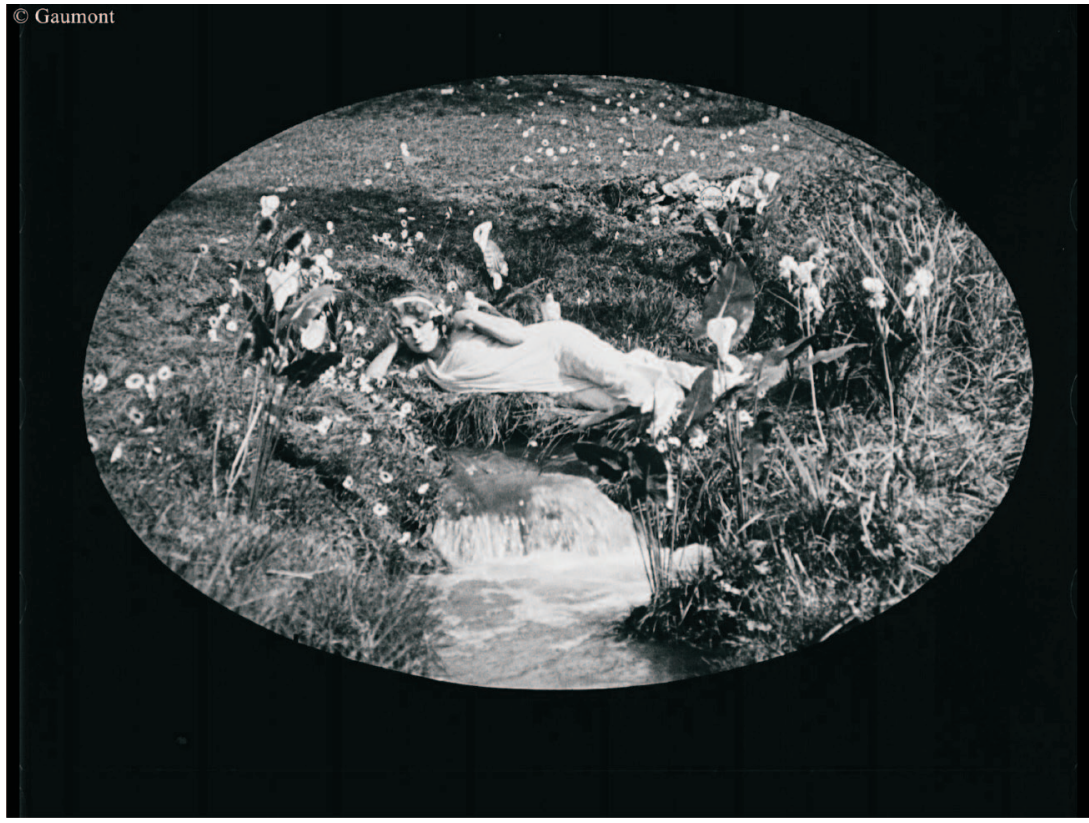




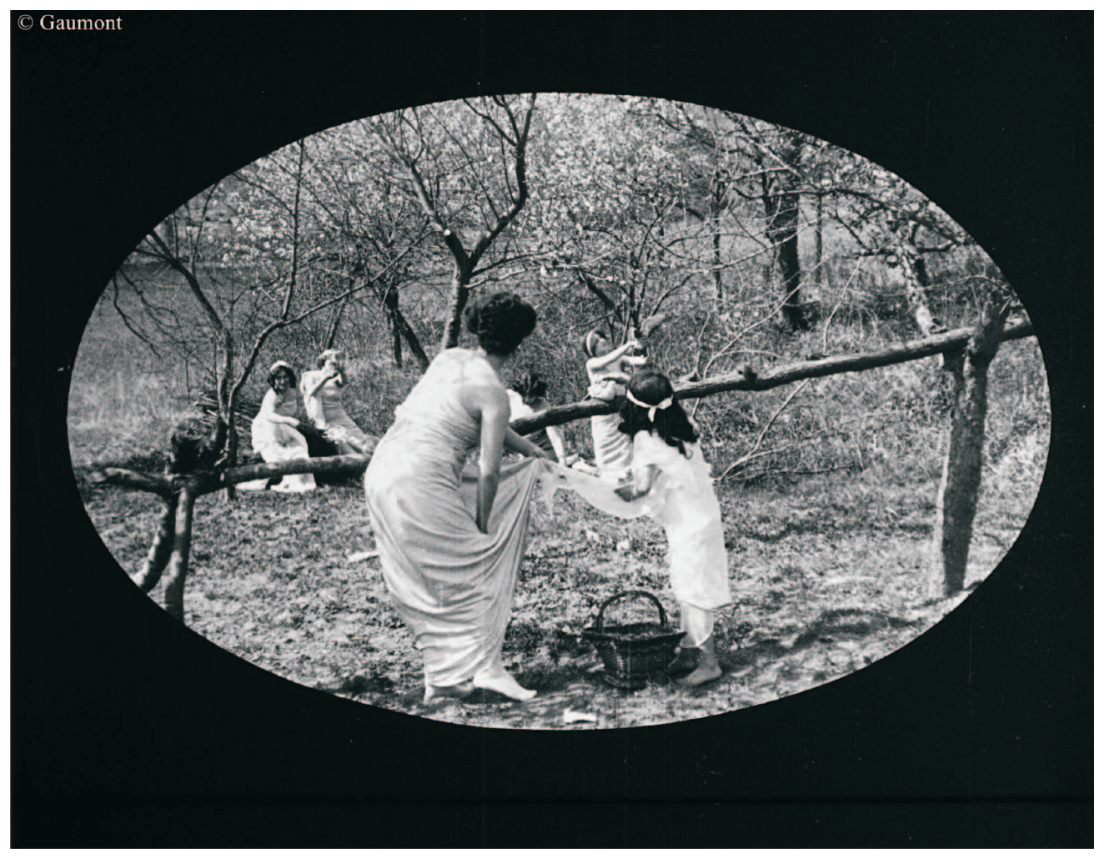

Figure 8. L'Éventail animé (Émile Cohl, F 1909, (c Gaumont).

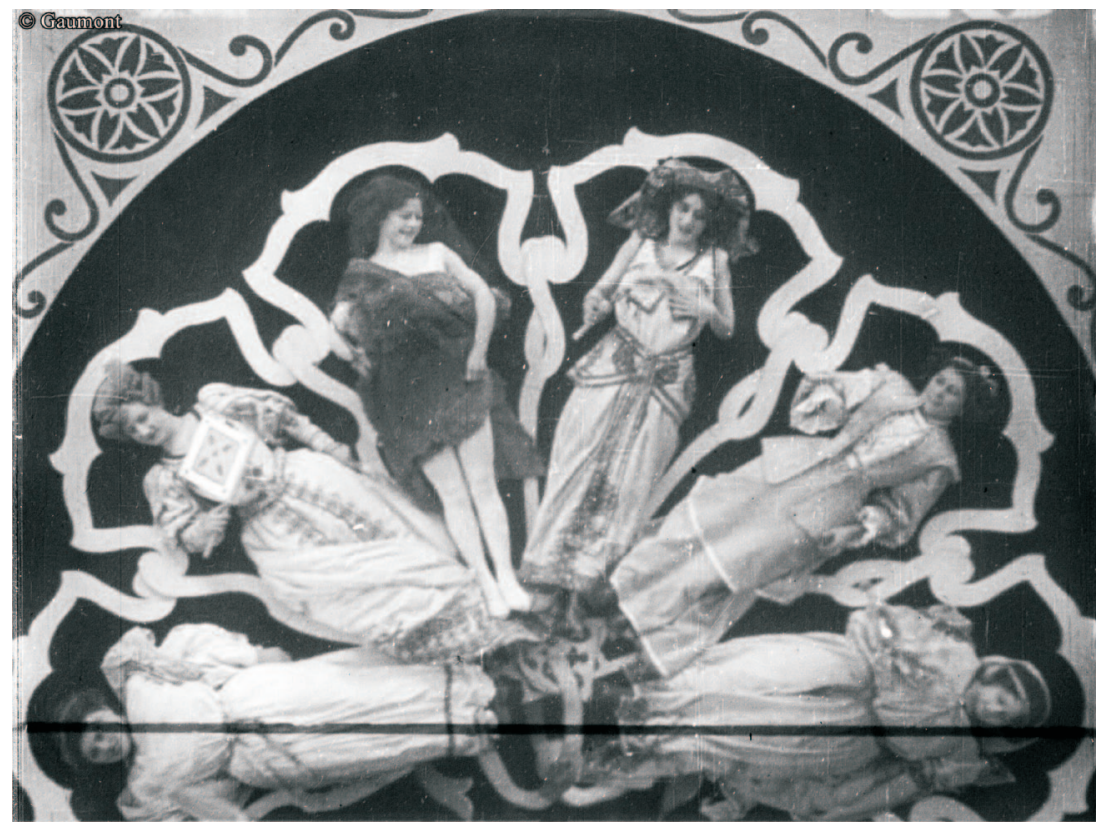


Figure 9. Picture of Dr. Angelo's Living Fan. Moderne Kunst (monthly edition) XIX/11, 1904/05: 267.

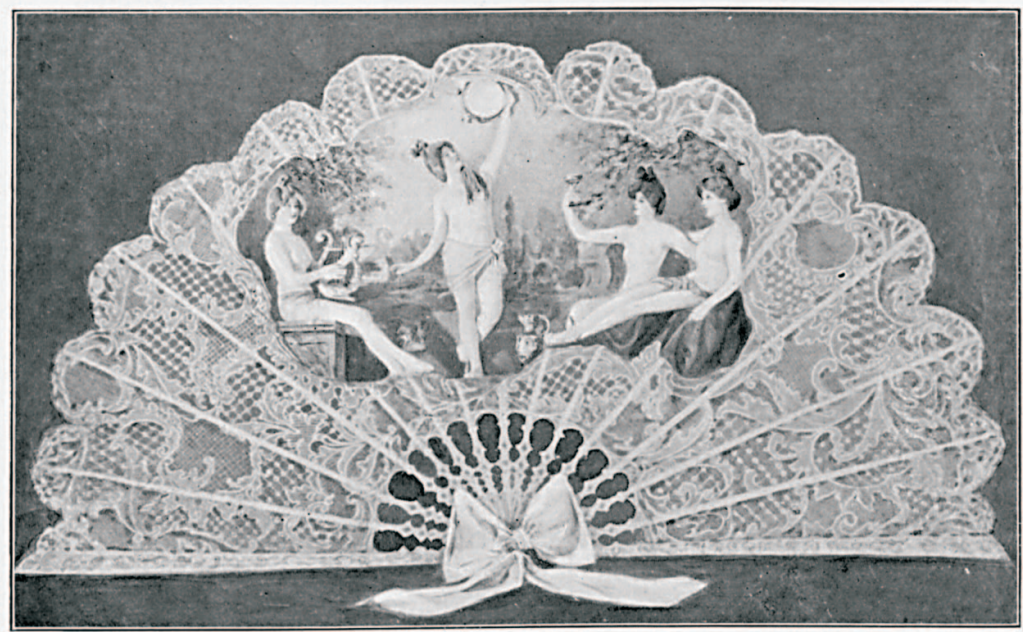

Dr. Angelos „Lebender Făcher ${ }^{a}$.

Figure 10. L'Éventail animé (Émile Cohl, F. 1909, (c) Gaumont), Figure 11. Porcelaines tendres (Émile Cohl, F. 1909, @ Gaumont).
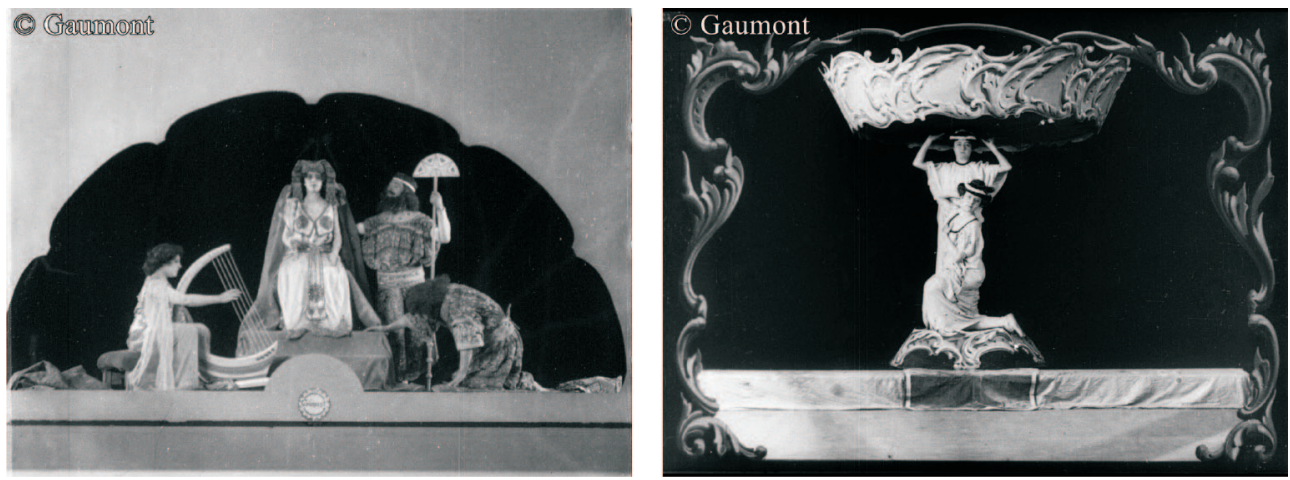